\title{
CONCEPÇÕES DE MONITORES E ALUNOS SOBRE O CONCEITO DE BIODIVERSIDADE EM UMA ATIVIDADE DE TRABALHO DE CAMPO
}

\author{
Luziene Aparecida Grandi ${ }^{1}$ \\ Rafael Gil de Castro² \\ Marcelo Tadeu Motokane ${ }^{3}$ \\ Danilo Seithi Kato 4
}

\begin{abstract}
RESUMO: O presente trabalho aborda aspectos da educação para a biodiversidade em espaço não formal de ensino, sendo a pesquisa realizada no projeto Trilhas da Biodiversidade. $O$ objetivo desta pesquisa foi verificar a influência das concepções de biodiversidade dos monitores deste projeto na escrita dos alunos visitantes. Foram realizadas entrevistas com os monitores juntamente com a análise de redações feitas pelos alunos após a visita ao projeto. Nas entrevistas, pode-se notar na fala dos monitores a presença dos três níveis hierárquicos da biodiversidade (genético, de espécies e 0 ecossistêmico). Além disso, foi encontrada duas novas concepções a respeito deste conceito, em que estão relacionadas com as Ciências Humanas. No tocante à escrita dos alunos, verifica-se na grade de análise das redações que, das múltiplas abordagens constatadas nas falas dos monitores, somente aquela relacionada à diversidade de espécies foi encontrada. Ao evidenciar esta lacuna entre as concepções dos monitores e a escrita dos alunos a respeito do conceito de biodiversidade, este trabalho proporciona alguns pontos a serem refletidos no que tange à educação para a biodiversidade em espaços não formais de ensino.
\end{abstract}

Palavras-chave: Educação para a biodiversidade; Trabalho de campo; Espaço não formal de ensino.

ABSTRACT: This paper discusses aspects of biodiversity education in nonformal teaching space, in which the survey was conducted in Trilhas da Biodiversidade project. The objective of this research was to investigate the influence of conceptions of biodiversity monitors of this project in writing of the visiting students. Interviews with the monitors were conducted along with analysis of essays from the students after the visit to the project. In the interviews, it can be noted in the speech monitors the presence of three hierarchical levels of biodiversity (genetic, species and ecosystem). In addition, two new conceptions

\footnotetext{
${ }^{1}$ Doutoranda em Biologia Comparada pela Universidade de São Paulo (USP). Bolsista CAPES. Contato: luzienegrandi@gmail.com

2 Mestrando em Ensino de Ciências pela Universidade de São Paulo (USP). Contato: rafacastro07@hotmail.com

${ }^{3}$ Docente do Departamento de Biologia da Faculdade de Filosofia, Ciências e Letras de Ribeirão Preto - Universidade de São Paulo (USP). Doutor em Educação pela Universidade de São Paulo (USP). Contato: mtmotokane@ffclrp.usp.br

${ }^{4}$ Docente da Universidade Federal do Triângulo Mineiro (UFTM). Doutorando em Educação Escolar pela Universidade Estadual Paulista "Júlio de Mesquita Filho" (UNESP) - Araraquara. Contato: katosdan@yahoo.com.br
} 
regarding this concept, in which are related to the Human Sciences, were found. Concerning the students' writing, it appears in the analysis grid of essays that the multiple approaches found in the speeches of the monitors, only one related to the diversity of species was found. Showing the gap between the monitor's concepts and the students' writing about the concept of biodiversity, this work provides some points to be reflected in relation to biodiversity education in nonformal teaching spaces.

Keywords: Education for biodiversity; Field work; Non-formal teaching space.

\section{INTRODUÇÃO}

Apesar do conceito biodiversidade atualmente ser muito utilizado nas Ciências Biológicas, ele foi cunhado em 1986 na cidade de Washington (Estados Unidos), durante o National Forum on BioDiversity. Neste mesmo fórum, organizado pela National Academy of Sciences e o Smithsonian Institution, os resumos foram publicados dois anos depois, em 1988, com o título de BioDiversity, tornando-se um livro de referência importante para a área. Dentre os autores dos resumos estavam especialistas de diversas áreas do conhecimento, como a Economia, Filosofia, Direito, Biologia, Antropologia, etc (MOTOKANE, 2005).

Seis anos depois, o termo biodiversidade figura como o centro das discussões durante a conferência mundial sobre o meio ambiente (ECO-92), promovida pela UNESCO no Rio de Janeiro. Durante o evento, 179 países ratificaram a "Convenção sobre a Diversidade Biológica", a CDB (MOTOKANE, 2005). Neste documento não há menção à palavra biodiversidade, mas sim a expressão diversidade biológica, em que é definida no artigo 2:

Diversidade Biológica significa a variabilidade de organismos vivos de todas as origens, compreendendo, dentre outros, os ecossistemas terrestres, marinhos e outros ecossistemas aquáticos e os complexos ecológicos de que fazem parte; compreendendo ainda a diversidade dentro de espécies, entre espécies e de ecossistemas (BRASIL, 1992; p. 9, CDB Artigo 2).

Após estes dois eventos globais, o conceito de biodiversidade torna-se foco de assuntos políticos e econômicos. Além disso, também começam a surgir na comunidade científica diversas definições sobre o termo (OLIVEIRA, 2005). 
Wilson publica em 1997 o livro "Biodiversity II: understanding and protecting our biological resources", em que sistematiza e conceitua o termo biodiversidade. No primeiro capítulo o autor define a biodiversidade como sendo toda variação existente nos diversos níveis de organização da vida, desde os genes de uma população local até as espécies que compõem esta comunidade, ou mesmo até a variação existente no conjunto dessas comunidades que compõem a parte viva dos ecossistemas. Portanto, para Wilson (1997), a compreensão da biodiversidade se dá na observação precisa de qual nível de organização se está interessado.

Lévêque descreve com mais detalhes os três níveis interligados da hierarquia biológica:

- A diversidade das espécies: A identificação das espécies e seu inventário constituem a maneira mais simples de apreciar a diversidade biológica de uma área geográfica. Foi a evolução biológica que deu forma, no decorrer do temo, a esta imensa diversidade de formas e de espécies.

- A diversidade genética: Cada espécie é diferente das outras do ponto de vista da sua constituição genética (genes, cromossomos). Da mesma forma, as pesquisas em biologia molecular colocaram em evidência a existência de uma variabilidade genética entre populações isoladas pertencentes a uma mesma espécie, bem como entre indivíduos no seio de uma população. A diversidade genética é o conjunto da informação genética contida dentro de todos os seres vivos, correspondendo à variabilidade dos genes e dos genótipos entre espécies e no seio de cada espécie.

- A diversidade ecológica: Os ecossistemas estão constituídos pelos complexos de espécies (ou biocenoses) e seu ambiente físico. Distinguimos numerosos tipos de ecossistemas naturais, como as florestas tropicais, os recifes de coral, os manguezais, as savanas, as tundras, etc., bem como os ecossistemas agrícolas. Cada um destes ecossistemas abriga uma combinação característica de plantas e de animais. Esses próprios ecossistemas evoluem em função do tempo, sob o efeito das variações climáticas sazonais ou a longo prazo. (LÉVÊQUE, 1999, p.16-18)

Ao serem analisadas as definições do conceito biodiversidade citadas neste trabalho, pode-se notar que existe um plano básico para a observação da biodiversidade dentro das áreas de conhecimento da Biologia. Há uma convergência em atribuir três eixos estruturais à biodiversidade: a diversidade genética, a diversidade de espécies e a diversidade de ecossistemas. Além 
disso, deve-se compreender que a biodiversidade ultrapassa a visão fragmentada de cada um dos eixos estruturais, uma vez que ela não é um simples catálogo de genes, espécies ou ambientes, mas sim resultado da interação dinâmica entre estes três níveis hierárquicos. Analisando mais profundamente o conceito, nota-se que esta dinâmica evidencia as flutuações genéticas entre as espécies juntamente com as variações do meio em que vivem, ou seja, explica, de certo modo, os processos evolutivos relacionados à diversificação das espécies e dos ecossistemas. Segundo Lévêque (1999), sob esse aspecto a biodiversidade auxiliaria na identificação dos fatores responsáveis pela origem e conservação da diversidade biológica nos diferentes níveis hierárquicos da Biologia.

Embora haja uma relativa concordância sobre o significado do conceito da biodiversidade entre os biólogos, o mesmo não ocorre com outros profissionais. Quando a biodiversidade é vista sob a óptica de recursos naturais, por exemplo, ela apresenta outras demandas de análise, que tangenciam dimensões éticas, econômicas e estéticas (MOTOKANE, 2005). No entanto, para Lévêque (1999) isso não é necessariamente um problema, mas sim um reflexo das preocupações disciplinares que cada área do conhecimento apresenta, sendo os cientistas mais interessados nos inventários e na dimensão ecológica, os políticos voltados para a dimensão econômica enquanto organizações não governamentais e de conservação da natureza estão mais preocupadas com a dimensão ética. Para o autor, a biodiversidade é um conceito federativo, que une os sistemas ecológicos aos sociais e que pode possibilitar a valorização e a gestão dos recursos naturais.

Como foi apresentado, o conceito de biodiversidade possui múltiplas abordagens. Discuti-lo é uma tarefa necessária (embora não seja simples), pois os temas relacionados ao meio ambiente são de importância para toda a população, extrapolando os interesses da comunidade científica (MOTOKANE et. al., 2010). Nesse sentido, as questões ambientais se tornam um foco de interesse na educação, uma vez que ensinar a preservar o meio significa ensinar a compreender os conhecimentos científicos e suas relações com a sociedade. Em espaços formais ou não formais de ensino, o trabalho com a educação para a biodiversidade implica a discussão dos domínios científico, cultural e social, 
sendo este um conceito integrador de vários conhecimentos na ecologia. Nestas situações de ensino há um grande potencial para que ocorra a formação de um cidadão crítico, capaz de tomar decisões e agir de forma coerente e responsável, diante dos problemas contemporâneos (incluindo questões ambientais) (CHERIF, 1992).

Tomando por base o que foi apresentado até o momento, o objetivo deste trabalho é identificar as concepções dos monitores de uma trilha em ambiente reflorestado sobre o conceito de Biodiversidade e sua influência na escrita dos alunos visitantes durante uma atividade de trabalho de campo.

\title{
METODOLOGIA
}

\author{
1. Local de estudo \\ O estudo ocorreu na Universidade de São Paulo, campus de Ribeirão
} Preto, durante uma atividade de trabalho de campo desenvolvida no Laboratório de Ensino de Biologia e na área de reflorestamento, também chamada de Floresta da USP (Figura 1). Esta atividade integra o Projeto de Cultura e Extensão Trilhas da Biodiversidade que objetiva estimular a reflexão sobre a preservação e conservação da fauna e flora da região de Ribeirão Preto, estimulando a percepção do meio ambiente e a valorização da biodiversidade local, ou seja, dando importância ao patrimônio natural por meio do contato direto com a floresta a partir do conhecimento biológico. 


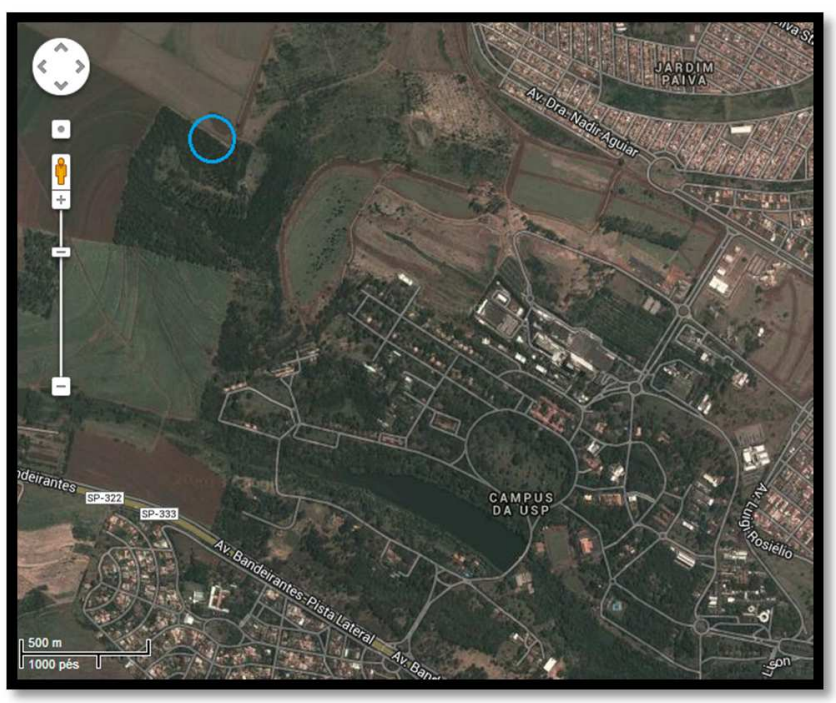

Figura 1. Mapa do campus de Ribeirão Preto, Universidade de São Paulo. O círculo em azul na parte superior do mapa destaca a região de reflorestamento onde ocorrem as atividades de campo do projeto Trilhas da Biodiversidade. Disponível em: $<$ https://maps.google.com.br/?|l=-21.164603,-47.852111\&spn=0.024373,0.042272\&t=h\&z=15>.

\section{Sequência didática e público alvo}

Três monitores, discentes da mesma universidade (um cursando Ciências Biológicas e dois, Licenciatura em Ciências), desenvolveram a sequência didática da atividade de trabalho de campo (Tabela 1) junto a uma turma de alunos de uma escola particular, proveniente do $9^{\circ}$ ano do ensino fundamental (totalizando 22 participantes).

Tabela 1. Síntese do roteiro da sequência didática do trabalho de campo

\begin{tabular}{|l|l|l|}
\hline \multicolumn{2}{|c|}{ Síntese do roteiro da sequência didática do trabalho de campo } \\
\hline $\begin{array}{l}\text { Apresentação e } \\
\text { contextualização do } \\
\text { problema do trabalho } \\
\text { de campo }\end{array}$ & $>\begin{array}{l}\text { Ida ao Laboratório de Ensino de Biologia; } \\
\text { Reflexão acerca do que é uma floresta e sobre as diferenças } \\
\text { existentes entre outras florestas; }\end{array}$ \\
& $>\begin{array}{l}\text { Introdução da problemática que será investigada durante o } \\
\text { trabalho de campo, relacionada ao efeito de borda; }\end{array}$ \\
& $\begin{array}{l}\text { Instruções sobre como os dados serão coletados na área de } \\
\text { reflorestamento. }\end{array}$ \\
\hline $\begin{array}{l}\text { Coleta de dados na área } \\
\text { de reflorestamento }\end{array}$ & $>\begin{array}{l}\text { Ida a dois quadrantes demarcados no reflorestamento, } \\
\text { localizados na área de borda e na área de interior; } \\
\text { Coleta de dados relacionados à abertura do dossel, altura das } \\
\text { árvores, PAP (Perímetro a Altura do Peito); quantidade de } \\
\text { serapilheira; fuste; quantidade de matéria orgânica presente no } \\
\text { solo. }\end{array}$ \\
\hline
\end{tabular}


Discussão dos dados coletados na área de reflorestamento
$>$ Retorno ao Laboratório de Ensino de Biologia;

$>$ Plotagem dos dados coletados em gráficos;

$>$ Discussão das possíveis causas de cada dado mensurado e resposta ao problema do trabalho de campo.

Inicialmente, foram apresentados aos alunos três modelos de distribuição de fragmentos de mata com vegetação nativa dentro de uma fazenda com plantação de monocultura de cana-de-açúcar (Figura 2). Como problema central da atividade, os alunos deveriam escolher um dos modelos para implantar na fazenda de forma que houvesse uma maior garantia da conservação da biodiversidade.
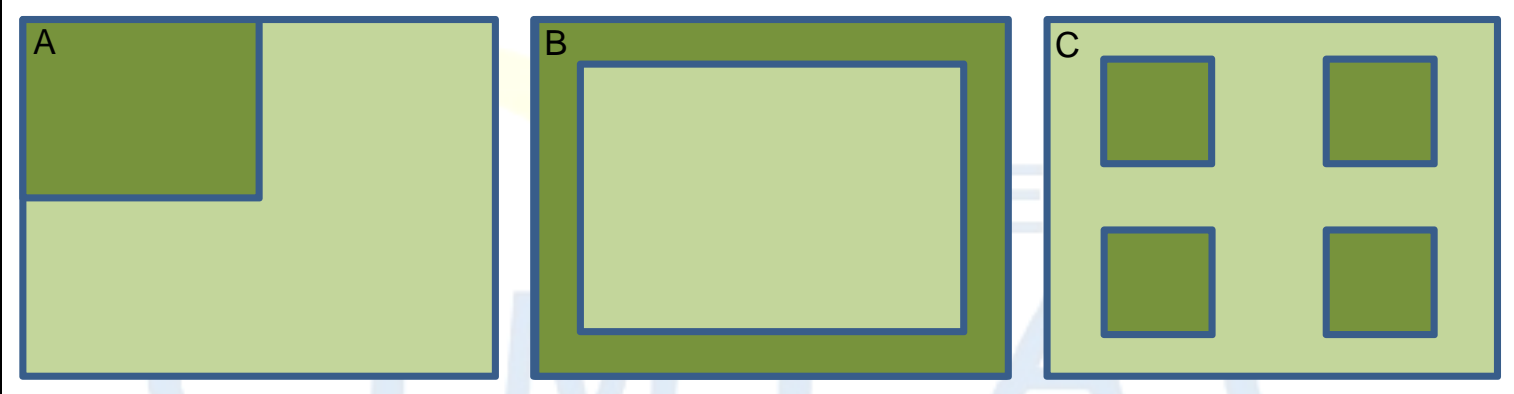

Fragmento de mata

Monocultura de cana-de-açúcar

Figura 2. Figura representando os modelos apresentados pelos monitores na introdução da problemática central do trabalho de campo.

A partir da introdução do problema do trabalho de campo, a sequência didática transcorreu. Alunos e monitores se dirigiram para a área de reflorestamento em dois quadrantes (um localizado na área de borda e outro na área de interior da Floresta da USP) para coletar dados por meio de metodologias da Ecologia. Após a coleta, retornaram ao Laboratório de Ensino de Biologia para discutir os dados coletados, relacioná-los e responder ao problema do trabalho de campo.

Posteriormente, na escola, a professora destes alunos pediu que escrevessem redações dizendo o que entenderam sobre o passeio na Universidade de São Paulo. 


\section{Objeto de estudo}

\subsection{Entrevistas}

Entrevistas semiestruturadas foram realizadas com os três monitores, guiadas por um roteiro que auxiliasse o entendimento sobre as suas concepções em relação ao conceito de biodiversidade presente no desenvolvimento da sequência didática do trabalho de campo (Tabela 2). Estiveram presentes questões que buscaram caracterizar os sujeitos de pesquisa, investigar a fonte primária na qual os entrevistados leram a respeito do conceito de biodiversidade, qual era a concepção que tinham sobre este mesmo conceito e de que forma e em quais momentos ele era abordado durante o trabalho de campo. Todas as entrevistas foram filmadas e transcritas de acordo com as normas observadas por Preti (1999).

Tabela 2. Roteiro semiestruturado da entrevista com os monitores do Projeto Trilhas da Biodiversidade.

1. Quais foram as fontes bibliográficas, referentes ao conceito de biodiversidade, consultadas para a montagem das atividades do Trilhas (artigos científicos, livros didáticos ou acadêmicos, revistas, sites e etc)?

2. O que vocês leram/estudaram para montar as atividades do Trilhas? Vocês chegaram a ler algum artigo científico, livro didático?

3. E para o conceito de biodiversidade, que é complexo e amplo, como que vocês fizeram?

4. Como foi pensada a transposição dos conteúdos estudados para a execução do projeto?

5. A partir do material que vocês leram, como vocês pensaram na adaptação desse conteúdo para os alunos?

6. De onde vocês tiraram a ideia pra fazer esse experimento? Como pensaram na adaptação do experimento para os alunos?

7. Algum fator além da bibliografia consultada influenciou vocês durante a transposição didática?

8. Teve algum outro fator além desses textos (materiais) que vocês utilizaram para as atividades do Trilhas da Biodiversidade? Alguma reportagem na TV, algo que estava acontecendo na sociedade mesmo, ou até mesmo um assunto que tenha partido dos próprios alunos?

9. Quais foram as dificuldades que o grupo encontrou para trabalhar com o conceito de biodiversidade?

10. Quais práticas vocês mudaram ao longo do desenvolvimento do projeto?

11. Qual é o conceito de biodiversidade adotado por vocês? 
Em um segundo momento ocorreu a análise das transcrições das entrevistas, procurando categorizar as falas dos monitores quanto a características que demarcassem as diversas compreensões correspondentes ao conceito de biodiversidade.

\subsection{Redações}

As redações foram analisadas com base em uma grade de análise construída a partir da leitura e reflexão de Gómez e Bernat (2010). A partir do artigo destes autores, a base conceitual do texto escrito redigido pelos alunos foi analisada de acordo com nove características (Tabela 3):

Tabela 3. Características definidas para a análise da base conceitual presente nas redações dos alunos.

\begin{tabular}{|ll|}
\hline 1. & A palavra biodiversidade aparece na produção textual? \\
\hline 2. & Formula perguntas embasadas no conhecimento científico? \\
\hline 3. & $\begin{array}{l}\text { Permite variação nas premissas à medida que entra em contato com novas } \\
\text { informações? }\end{array}$ \\
\hline 4. & Considera problemas sob diferentes perspectivas? \\
\hline 5. & Os conceitos da maneira que são utilizados conferem maior consistência e \\
& qualidade à interpretação realizada acerca das políticas em torno da \\
& Biodiversidade? \\
\hline 6. & Quais os conceitos e valores, relacionados à biodiversidade, que mais aparecem \\
& quando o trabalho de campo é mencionado? \\
\hline 7. & Como a biodiversidade é compreendida e em que nível? \\
\hline 8. & Torna os conceitos relativos à biodiversidade significativos em diferentes contextos \\
\hline 9. & Os conceitos relacionados à biodiversidade e à sua conservação são tratados de \\
& forma prática e contextualizada? \\
\hline
\end{tabular}

Após a análise das entrevistas e das redações houve uma tentativa de entender os dados conjuntamente, de forma a verificar se as concepções de biodiversidade dos monitores interferiram de alguma forma nas concepções de biodiversidade presentes nos textos dos alunos. 


\section{RESULTADOS E DISCUSSÃO}

\section{Categorização das falas dos monitores nas entrevistas}

As categorias e subcategorias de análise dos dados foram organizadas conforme a ocorrência de termos e expressões específicos nas falas dos indivíduos e agrupadas de acordo com a natureza do conhecimento que abrangem. Nesse sentido, as falas dos monitores foram agrupadas em duas categorias: biológica e social.

A categoria biológica foi baseada em Oliveira (2010) e expressa os níveis de biodiversidade encontrados na literatura acadêmica. Esta categoria apresenta três subdivisões: a diversidade genética, diversidade de espécies e diversidade de ecossistemas. A diversidade genética corresponde a todo e qualquer tipo de variação da constituição gênica nos mais variados níveis hierárquicos da biologia (indivíduo, espécie, população). Por outro lado, a categoria de diversidade de espécies representa a definição mais clássica de biodiversidade, sendo caracterizado pelo número de espécies de determinado local. A última categoria, a diversidade de ecossistemas, trata da relação entre os organismos com o meio em que vivem, podendo ser a diversidade de processos ecológicos (desde as relações entre um organismo e o meio em que este vive, até as relações entre os organismos, tais como competição, predatismo, parasitismo) e também a diversidade de habitats.

Acrescida a estas, nesta pesquisa foi encontrada outra categoria, aqui identificada como social. Tal categoria foi subdividida em diversidade econômica e diversidade cultural. Na presente pesquisa, a subcategoria econômica representa as diferentes classes sociais que podem ser encontradas em nossa sociedade e que são distinguidas de acordo com o poder aquisitivo que apresentam. Por fim, a subcategoria diversidade cultural, mais abrangente do que a anterior, representa a diversidade de costumes, valores, dentre outros aspectos que englobam as diferenças culturais encontradas na sociedade (desde a escala regional até a mundial).

A tabela 4 evidencia, de maneira resumida, a definição das categorias e subcategorias do conceito de biodiversidade. 
Tabela 4. Definição das categorias e subcategorias do conceito de biodiversidade.

\begin{tabular}{|c|c|c|}
\hline Categoria & Subcategoria & Definição \\
\hline \multirow{3}{*}{ Biológica } & Diversidade Genética (D.G.) & $\begin{array}{l}\text { Qualquer tipo de variação da constituição } \\
\text { gênica nos mais variados níveis } \\
\text { hierárquicos da biologia (indivíduo, } \\
\text { espécie, população...). }\end{array}$ \\
\hline & $\begin{array}{l}\text { Diversidade de Espécies } \\
\text { (D.Es) }\end{array}$ & $\begin{array}{l}\text { Número de diferentes espécies de } \\
\text { determinado local, ou seja, a riqueza de } \\
\text { espécies (MELO, 2008). }\end{array}$ \\
\hline & $\begin{array}{l}\text { Diversidade de } \\
\text { Ecossistemas (D.Ec.) }\end{array}$ & $\begin{array}{l}\text { Representa a relação entre os organismos } \\
\text { com o meio em que vivem, podendo ser a } \\
\text { diversidade de processos ecológicos } \\
\text { (desde as relações entre um organismo e } \\
\text { o meio em que este vive, até as relações } \\
\text { entre os organismos, tais como } \\
\text { competição, predatismo, parasitismo e etc) } \\
\text { e também a diversidade de habitats. }\end{array}$ \\
\hline \multirow{2}{*}{ Social } & $\begin{array}{l}\text { Diversidade Econômica } \\
\text { (D.Econ.) }\end{array}$ & $\begin{array}{l}\text { Representa as diferentes classes sociais } \\
\text { que podem ser encontradas em nossa } \\
\text { sociedade e que são distinguidas de } \\
\text { acordo com o poder aquisitivo que } \\
\text { apresentam. }\end{array}$ \\
\hline & Diversidade Cultural (D.C.) & $\begin{array}{l}\text { Representa a diversidade de costumes, } \\
\text { valores, dentre outros aspectos que } \\
\text { englobam as diferenças culturais } \\
\text { encontradas na sociedade (desde a escala } \\
\text { regional até a mundial). }\end{array}$ \\
\hline
\end{tabular}

A tabela 5 apresenta exemplos de como estas categorias e subcategorias aparecem nas falas dos monitores.

Tabela 5. Categorias e subcategorias do conceito de biodiversidade com exemplos de falas dos monitores, retiradas das entrevistas.

\begin{tabular}{|c|c|l|l|l|}
\hline Categorias & Subcategorias & \multicolumn{1}{c|}{ Monitor 1 } & Monitor 2 & \multicolumn{1}{c|}{ Monitor 3 } \\
\hline $\begin{array}{c}\text { Diversidade } \\
\text { Genética }\end{array}$ & $\begin{array}{l}\text { "eles não conseguiam ver } \\
\text { a questão da variabilidade } \\
\text { genética na mesma } \\
\text { espécie isso também é } \\
\text { uma questão de } \\
\text { biodiversidade..." }\end{array}$ & & $\begin{array}{l}\text { "então a ideia naquela } \\
\text { época era divulgar a } \\
\text { importância do banco } \\
\text { genético mostrar que nós } \\
\text { temos um banco genético } \\
\text { explicar o que significa } \\
\text { banco genético... dai } \\
\text { entrava naquela parte de } \\
\text { diversidade é:: é::: } \\
\text { diversidade alélica né? e } \\
\text { diversidade é:: } \\
\text { ge/ge/genética mesmo...." }\end{array}$ \\
Biológica & & & & \\
\hline
\end{tabular}




\begin{tabular}{|c|c|c|c|c|}
\hline & $\begin{array}{l}\text { Diversidade de } \\
\text { Espécies }\end{array}$ & $\begin{array}{l}\text { "é:: a questão de } \\
\text { diferenças (...) eles não vê } \\
\text { a diferença de árvore." }\end{array}$ & $\begin{array}{l}\text { "ai a gente trabalhou (...) a } \\
\text { diversidade de árvores e de } \\
\text { insetos que aparece ou } \\
\text { alguns animais também" }\end{array}$ & $\begin{array}{l}\text { "as diferenças das bióticas } \\
\text { de certa forma } \\
\text { mostravam... é:: a-a-a/ } \\
\text { uma questão de } \\
\text { observação mesmo... então } \\
\text { se a gente ia na borda eles } \\
\text { percebiam muito mais } \\
\text { capim colonial ... eles viam } \\
\text { a morfologia das-das-das } \\
\text { folhas... eu tentava chamar } \\
\text { atenção a que tipo de folha } \\
\text { tem na serapilheira?" }\end{array}$ \\
\hline & $\begin{array}{c}\text { Diversidade de } \\
\text { Ecossistemas }\end{array}$ & $\begin{array}{l}\text { "na trilha eu acho que o } \\
\text { conceito de biodiversidade } \\
\text { ele fica mais pautado na } \\
\text { questão florestal mesmo } \\
\text { na questão de borda- } \\
\text { interior" }\end{array}$ & $\begin{array}{l}\text { "que isso tá atrelado nicho } \\
\text { ecológico dos animais... a } \\
\text { cadeia alimentar nível } \\
\text { trófico assim... mais esse } \\
\text { conceito mesmo..." }\end{array}$ & $\begin{array}{l}\text { "então eles percebiam um } \\
\text { número maior de } \\
\text { interações e como eu falei } \\
\text { biodiversidade tá como } \\
\text { pano de fundo né? pra ter } \\
\text { um maior número de } \\
\text { interações teria um maior } \\
\text { número de biodiversidade" }\end{array}$ \\
\hline \multirow[t]{2}{*}{ Social } & $\begin{array}{l}\text { Diversidade } \\
\text { Econômica }\end{array}$ & $\begin{array}{l}\text { "né ou diferenças de } \\
\text { costumes até ah uma } \\
\text { classe social maior tem um } \\
\text { costume diferente de uma } \\
\text { classe social já mais:: mais } \\
\text { humilde... é:: questão de } \\
\text { comportamento...é:: uma } \\
\text { questão que está } \\
\text { relacionada com o meio } \\
\text { né... e eu também posso } \\
\text { chamar isso de uma } \\
\text { biodiversidade" }\end{array}$ & 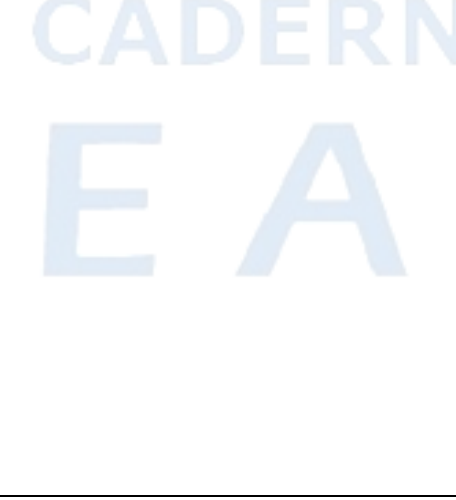 & \\
\hline & $\begin{array}{c}\text { Diversidade } \\
\text { Cultural }\end{array}$ & $\begin{array}{l}\text { "tipo... é:: a questão da } \\
\text { diferença é:: cultural que } \\
\text { você encontra dentro de } \\
\text { uma parcela da sociedade" }\end{array}$ & $\begin{array}{l}\text { "dessa questão } \\
\text { sociocultural... então } \\
\text { trazer:: ah é:: trazer a } \\
\text { questão biodiversidade } \\
\text { mais pro aspecto } \\
\text { sociocultural assim pra... } \\
\text { tocar o aluno mesmo" }\end{array}$ & \\
\hline
\end{tabular}

\subsection{Presença de subcategorias nas falas dos monitores}

A Tabela 6 evidencia que o conhecimento biológico se fez presente em maior quantidade na fala dos monitores. Dentro desta categoria, o viés ecossistêmico foi o mais citado. Por outro lado, a subcategoria referente à diversidade genética foi a menos lembrada por todos os indivíduos durante a entrevista. 
Tabela 6. Quantificação da presença de subcategorias conforme o aparecimento nas falas dos indivíduos durante a entrevista.

\begin{tabular}{|c|c|c|c|c|c|c|}
\cline { 2 - 7 } \multicolumn{1}{c|}{} & D.G & D.Es & D.Ec & D.Econ & D.C & Total \\
\hline Monitor 1 & 2 & 3 & 3 & 1 & 1 & 10 \\
\hline Monitor 2 & 0 & 2 & 3 & 0 & 1 & 6 \\
\hline Monitor 3 & 2 & 4 & 5 & 0 & 0 & 11 \\
\hline Total & 4 & 9 & 11 & 1 & 2 & 27 \\
\hline
\end{tabular}

Uma das explicações para o fato de que a diversidade ecossistêmica tenha sido a mais citada pelos monitores ao longo da entrevista é a própria concepção ambiental do projeto, uma vez que o mesmo aborda aspectos ecológicos de uma área de reflorestamento, e isso se reflete na leitura utilizada pelos monitores para buscarem os conceitos de biodiversidade. Além disso, os idealizadores do projeto estão situados dentro de um laboratório que tem como linha de pesquisa trabalhos na área do Ensino de Ciências que abordam conceitos da Ecologia, o que também influencia diretamente nas diretrizes do Projeto Trilhas da Biodiversidade.

Essa abordagem ecossistêmica é de extrema importância quando se trata de biodiversidade, uma vez que o conceito de biodiversidade ainda está fortemente atrelado apenas à ideia da riqueza de espécies de determinada região (OLIVEIRA, 2005). Quando a biodiversidade é analisada apenas sob a óptica da diversidade de espécies (a segunda abordagem mais encontrada na fala dos monitores), o conceito perde sua abrangência ficando restrito, na maioria dos casos, à análise isolada de espécies animais e vegetais de determinado local.

O conhecimento presente na categoria social apareceu somente nos indivíduos que apresentam formação acadêmica em cursos que contemplam a área das Ciências Humanas (monitor 1 e monitor 2). Estes dois monitores buscaram este conhecimento de biodiversidade vinculado a uma gama complexa de interações que envolvem seus próprios conhecimentos de biodiversidade numa perspectiva biológica, o conhecimento proveniente de cada 
um de acordo com sua formação específica, as discussões de pesquisa no laboratório, e as próprias discussões com os idealizadores do projeto.

\section{Base conceitual presente nas redações escritas pelos alunos}

Poucos alunos citaram a palavra biodiversidade (6 redações) em suas produções escritas. Em uma minoria de redações ficou explícito o que os alunos entediam sobre o significado do conceito de biodiversidade (5 redações). Nestes últimos, em 3 redações o conceito de biodiversidade apareceu como diversidade de espécies, em uma redação apareceu como quantidade de plantas e em mais uma redação apareceu como diversidade de animais.

Tabela 7. Grade de análise com resumo dos resultados verificados nas redações.

\begin{tabular}{|c|c|c|}
\hline \multirow{2}{*}{\multicolumn{2}{|c|}{$\begin{array}{lc}\text { Turmas } & \text { Grade de Análise } \\
\end{array}$}} & 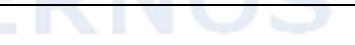 \\
\hline & & 9 ano \\
\hline \multicolumn{2}{|c|}{ Total de redações analisadas } & 22 \\
\hline & & $\begin{array}{l}\text { Número de redações } \\
\text { nas quais os itens } \\
\text { analisados estão } \\
\text { presentes }\end{array}$ \\
\hline \multirow[t]{9}{*}{$\begin{array}{l}\text { Base } \\
\text { conceitual }\end{array}$} & $\begin{array}{l}\text { A palavra biodiversidade aparece na produção } \\
\text { textual? }\end{array}$ & 6 \\
\hline & $\begin{array}{l}\text { Formula perguntas embasadas no conhecimento } \\
\text { científico? }\end{array}$ & 0 \\
\hline & $\begin{array}{l}\text { Permite variação nas premissas à medida que } \\
\text { entra em contato com novas informações? }\end{array}$ & 0 \\
\hline & $\begin{array}{l}\text { Considera problemas sob diferentes } \\
\text { perspectivas? }\end{array}$ & 0 \\
\hline & $\begin{array}{l}\text { Os conceitos da maneira que são utilizados } \\
\text { conferem maior consistência e qualidade à } \\
\text { interpretação realizada acerca das políticas em } \\
\text { torno da Biodiversidade? }\end{array}$ & 0 \\
\hline & $\begin{array}{l}\text { Quais os conceitos e valores, relacionados à } \\
\text { biodiversidade, que mais aparecem quando o } \\
\text { trabalho de campo é mencionado? }\end{array}$ & 0 \\
\hline & $\begin{array}{l}\text { Como a biodiversidade é compreendida e em que } \\
\text { nível? }\end{array}$ & $\begin{array}{c}3 \text { - diversidade de } \\
\text { espécies } \\
1 \text { - quantidade de } \\
\text { plantas } \\
1 \text { - diversidade de } \\
\text { animais }\end{array}$ \\
\hline & $\begin{array}{l}\text { Torna os conceitos relativos à biodiversidade } \\
\text { significativos em diferentes contextos }\end{array}$ & 0 \\
\hline & $\begin{array}{l}\text { Os conceitos relacionados à biodiversidade e à } \\
\text { sua conservação são tratados de forma prática e } \\
\text { contextualizada? }\end{array}$ & 0 \\
\hline
\end{tabular}


Das múltiplas abordagens mais constatadas nas falas dos monitores, somente a relacionada à diversidade de espécies (a segunda com maior frequência) foi constatada no texto escrito dos alunos.

Como a professora pediu que os alunos escrevessem o que haviam entendido sobre o passeio, a estrutura das redações traduziu-se em descrições das atividades realizadas, ressaltando as metodologias de coletas de dados presenciadas na área de reflorestamento durante o trabalho de campo. Todavia, não é possível dizer se este foi o motivo pelo qual outros itens considerados na base conceitual não apareceram. Devido à complexidade e à dificuldade de se ensinar e usar de forma contextualizada o conceito de biodiversidade, outros fatores podem ter determinado estes mesmos resultados, como a dificuldade de se posicionar refletido sobre os dados coletados e utilizando conhecimento científico para responder o problema central do trabalho de campo (o qual foi mencionado poucas redações).

\section{CONSIDERAÇÕES FINAIS}

A ausência de redações com os itens elencados na grade de análise dão margem a uma ampla discussão a respeito do ensino da biodiversidade quando interpretadas conjuntamente com outros dados, como os indícios obtidos a partir do estudo das entrevistas respondidas pelos monitores da atividade de trabalho de campo.

Embora haja um potencial pedagógico a ser trabalhado com a temática da biodiversidade, a verificação das entrevistas com os monitores evidenciou em suas falas somente duas abordagens que apareceram com maior frequência, enviesando o entendimento a respeito da biodiversidade.

Predominantemente, os monitores definiram o conceito de biodiversidade como uma abordagem ecossistêmica (relações ecológicas entre as espécies) e como variedade de espécies. Igualmente afirmaram que este conceito pode ser ensinado ao levar os alunos até a floresta da USP chamando a atenção destes para observarem as espécies lá existentes. 
Entretanto, ir a um ambiente natural e coletar dados (quantitativos ou qualitativos) não garante que o aluno compreenda o conceito de biodiversidade. Durante a atividade de trabalho de campo desenvolvida na área reflorestada, os alunos coletaram dados de acordo com metodologias provenientes da Ecologia, mas não discutiram questões sobre biodiversidade.

A análise das redações evidenciou estes apontamentos, pois a maioria dos alunos não cita o termo biodiversidade e os que citam, concebem biodiversidade como uma diversidade de espécies, quantidade de árvores ou diversidade de animais. De forma geral, os alunos falam mais das diferenças existentes entre a área de borda e a área de interior da floresta descrevendo os "experimentos", no entanto, não conseguem estabelecer relações entre as variáveis, respondendo ao problema do trabalho de campo. Os poucos que respondem qual figura representa a melhor disposição da floresta dentro de uma monocultura, de forma a preservar a biodiversidade, não conseguem justificar o porquê da escolha ou a justificam de forma incorreta.

O conceito de biodiversidade faz uma conexão entre os aspectos ecológicos e sociais da biosfera e, portanto, para que se possa compreendê-lo em sua totalidade faz-se necessário um esforço intelectual de vários ramos das Ciências, tanto Humanas quanto Biológicas e Exatas.

Destas observações surgem alguns questionamentos: em espaços de ensino não formais, como museus de ciências naturais, jardins zoológicos, jardins botânicos, realmente ocorre a Educação para a Biodiversidade? Há uma metodologia para abordar a biodiversidade em seus aspectos conceituais, procedimentais e axiológicos?

\section{REFERÊNCIAS BIBLIOGRÁFICAS}

BRASIL. Ministério do Meio Ambiente. Secretaria de Biodiversidade e Floretas. Convenção sobre Diversidade Biológica: Conferência para Adoção do Texto Acordado da CDB - Ato Final de Nairobi. Brasília: MMA/SBF, 2000.

CHERIF, A. H. Barriers to ecology education in North American high schools: another alternative perspective. Journal of Environment Education, v. 23, n. 3, p. 36-46. 1992. 
GÓMEZ, J.G.; BERNART, F.J.M. Cómo y qué enseñar de la biodiversidad en la alfabetización científica? Enseñanza de las ciências, v. 28, n. 2, p. 175-184. 2010.

LÉVÊQUE, C. A Biodiversidade. Bauru: EDUSC, 1999.

MOTOKANE, M. T. Educação e biodiversidade: elementos do processo de produção de materiais pedagógicos. Tese (Doutorado em Educação) Universidade de São Paulo, São Paulo, 2005.

MOTOKANE, M. T.; KAWASAKI, C. S.; OLIVEIRA, L. B. Por que a biodiversidade pode ser um tema para o ensino de ciências? In: MARANDINO, Martha; MONACO, Luciana Magalhães; OLIVEIRA, Adriano Dias de (Orgs.). Olhares sobre os diferentes contextos da biodiversidade: pesquisa, divulgação e educação. São Paulo: GEENF/FEUSP/INCTTOX, 2010, p. 30-60.

OLIVEIRA, A. D. Biodiversidade e museus de ciências: um estudo sobre transposição museográfica nos dioramas. Dissertação (Mestrado em Ciências) - Universidade de São Paulo, São Paulo, 2010.

PRETI, D. O discurso oral culto. São Paulo: Humanitas Publicações, 1999.

WILSON, E.O. Introduction. In: REAKA-KUDLA, M.L.; WILSON, D.E \& WINSON, E.O. Biodiversity II: understanding and protecting our biological resources. Washington: Joseph Henri Press, 1997.

\section{AGRADECIMENTOS}

Coordenação de Aperfeiçoamento de Pessoal de Nível Superior - CAPES.

Grupo de Pesquisa e Estudo em Linguagem e Ensino de Ciências - LINCE. 